\title{
Leptin in Early Life: A Key Factor for the Development of the Adult Metabolic Profile
}

\author{
Miriam Granado a, b Esther Fuente-Martín ${ }^{a} \quad$ Cristina García-Cáceres ${ }^{a}$ \\ Jesús Argente ${ }^{a}$ Julie A. Chowen ${ }^{a}$ \\ a Department of Endocrinology, Hospital Infantil Universitario Niño Jesús, Instituto de \\ Investigación La Princesa, Department of Pediatrics, Universidad Autónoma de Madrid and \\ CIBER Fisiopatología de Obesidad y Nutrición, Instituto de Salud Carlos III, ${ }^{b}$ Department of \\ Physiology, Facultad de Medicina, Universidad Autónoma de Madrid, Madrid, Spain
}

\section{Key Words}

Leptin · Metabolic programming $\cdot$ Hypothalamus $\cdot$ Adipose tissue

\begin{abstract}
Leptin levels during the perinatal period are important for the development of metabolic systems involved in energy homeostasis. In rodents, there is a postnatal leptin surge, with circulating leptin levels increasing around postnatal day (PND) 5 and peaking between PND 9 and PND 10. At this time circulating leptin acts as an important trophic factor for the development of hypothalamic circuits that control energy homeostasis and food seeking and reward behaviors. Blunting the postnatal leptin surge results in long-term leptin insensitivity and increased susceptibility to diet-induced obesity during adulthood. Pharmacologically increased leptin levels in the postnatal period also have long-term effects on metabolism. Nevertheless, this effect is controversial as postnatal hyperleptinemia is reported to both increase and decrease the predisposition to obesity in adulthood. The different effects reported in the literature could be explained by the different moments at which this hormone was administered, suggesting that modifications of the neonatal leptin surge at specific time points could selectively affect the development of central and peripheral systems that are undergoing modifications at this moment resulting in different metabolic and behavioral outcomes. In addition, maternal nutrition and the hormonal environment during pregnancy and lactation may also modulate the offspring's response to postnatal modifications in leptin levels. This review highlights the importance of leptin levels during the perinatal period in the development of metabolic systems that control energy homeostasis and how modifications of these levels may induce long-lasting and potentially irreversible effects on metabolism.




\section{Introduction}

Leptin is a 167 amino acid peptide mainly produced by adipose tissue [1] whose main function is to maintain body weight by regulating the balance between energy intake and expenditure [2]. Leptin mRNA and protein levels in adipose tissue and plasma are positively correlated with body fat and adipocyte size [3]. Thus, obese individuals generally have higher leptin mRNA and protein levels than lean individuals [4-5].

Leptin acts on feeding centers in the hypothalamus and other brain areas, modifying the expression and release of orexigenic and anorexigenic neuropeptides, including neuropeptide Y (NPY) and pro-opiomelanocortin (POMC). In the arcuate nucleus (ARC), NPY and POMC neurons express the long form of the leptin receptor (Lep-Rb), which is functionally coupled to the Janus kinase signal transducer-signaling pathway [6]. Although there are at least six alternatively spliced isoforms of the leptin receptor (Lep-Ra, $\mathrm{Rb}, \mathrm{Rc}, \mathrm{Rd}, \mathrm{Re}$ and $\mathrm{Rf}$ ) in mice [7], it is activation of Lep-Rb that is reported to be most involved in metabolic control. The shorter isoforms are thought to act as leptin transporters at different sites, including plasma and the blood-brain barrier $[8,9]$.

Binding of leptin to Lep-Rb results in phosphorylation of Janus activated kinases 1 (JAK-1) and 2 (JAK-2) and tyrosine phosphorylation of the cytoplasmic domain of Lep-Rb and downstream transcription factors of the signal transducer and activators of transcription (STAT) family. These signaling molecules are highly expressed in the hypothalamus, brainstem, and other brain regions that control food intake and autonomic and neuroendocrine functions [10]. Reduction in the sensitivity or activation of this signaling pathway results in leptin resistance and underlies the obese phenotype of $d b / d b$ mice and fatty rats $[7,11]$. Leptin's actions are terminated by induction of silencer of cytokine signaling 3 (SOCS-3), a member of a family of proteins induced by cytokines, that blocks the JAK-STAT signaling cascade by inhibiting leptin-mediated tyrosine phosphorylation of JAK-2 [12]. SOCS-3 may also play a role in leptin resistance as SOCS-3 levels are elevated in the ARC in diet-induced obese (DIO) mice, and this is associated with reduced sensitivity to leptin's effect on food intake, body weight, and neuropeptide secretion [13]. Protein-tyrosine phosphastase 1B (PTP-1B) is also a critical downstream regulator of leptin signal transduction $[14,15]$. Overexpression of PTP-1B decreases phosphorylation of JAK-2 and blocks leptininduced transcription of SOCS-3 and c-fos [16], while deletion of the PTP-1B gene enhances leptin sensitivity in mice, preventing obesity $[17,18]$. In addition to this cascade involving JAK-STAT, leptin also modulates other intracellular pathways including ERK, AMPK, PI3K, and cAMP [19, 20] (fig. 1).

Leptin's effects on metabolism are not limited to modifications in neuropeptide production or secretion, as it also induces rapid modifications in synaptic connectivity of neuronal populations involved in metabolic control [21] as well as in astrocyte morphology [22]. Leptin may also control food intake by modulating taste perception as this hormone selectively reduces the sweet taste response, most likely through direct action on the Lep-Rb expressed in sweet-sensitive receptor cells [23]. Leptin receptors are also expressed in areas involved in eating behavior [24-26], and this hormone has been shown to affect food seeking behavior, by modifying both the hedonic and motivational aspects of reward, anxiety, and food preference [27-30]. Furthermore, leptin not only regulates energy homeostasis by acting in the brain but also increases basal metabolism through stimulation of the sympathetic nervous system and thyroid hormones thus increasing energy expenditure [31]. 


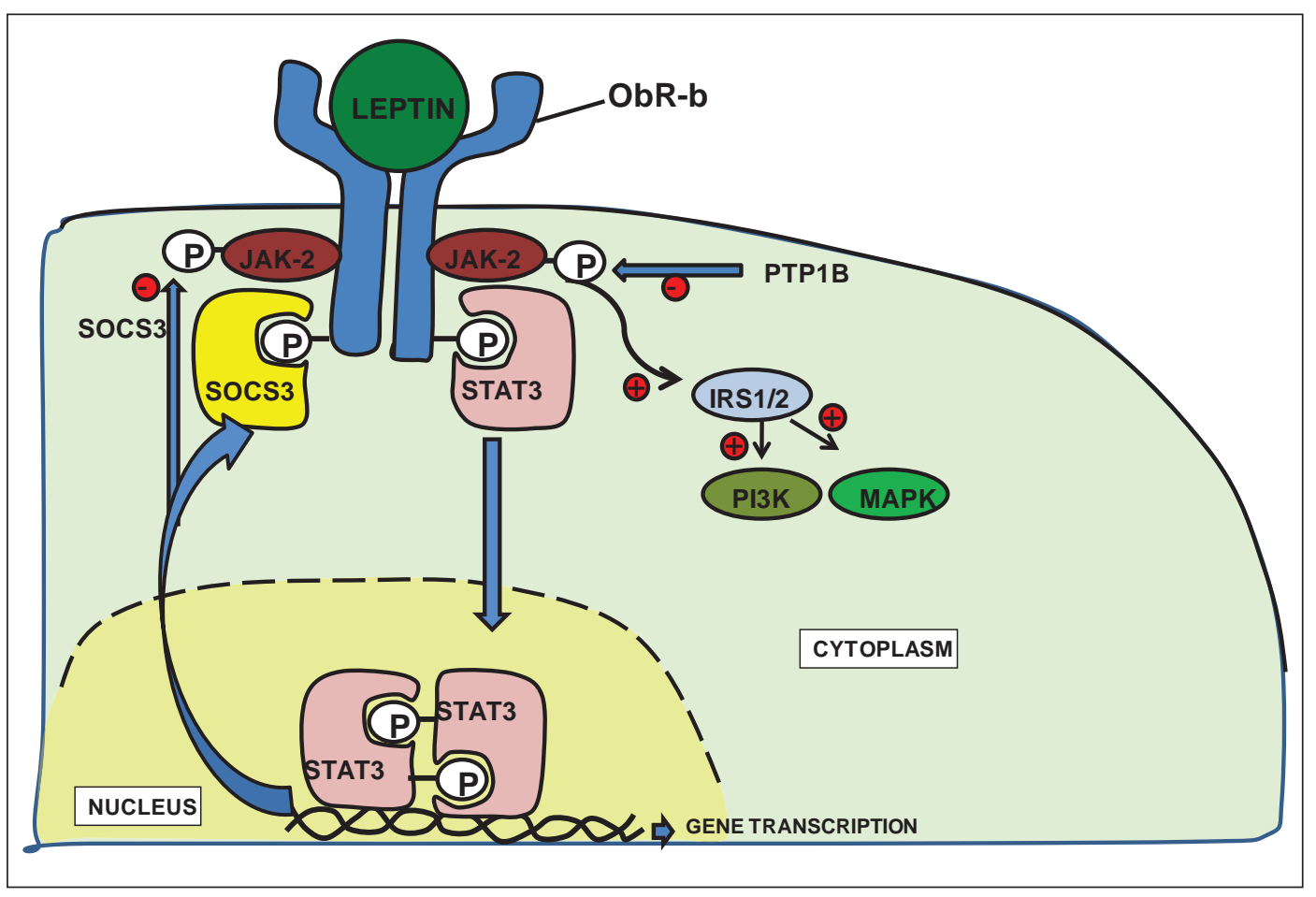

Fig. 1. Schematic representation of the intracellular signaling mechanisms of the leptin receptor $1 \mathrm{~b}$ (Lep-b): Leptin binds to the leptin receptor, which activates JAK-2 leading to nuclear translocation of STAT3 to mediate the transcriptional regulation of neuropeptides and SOCS-3. SOCS-3 and PTP-1B inhibits leptin signaling.

\section{Metabolic Programming: A General Overview}

In the last decades, the prevalence of obesity during childhood has dramatically increased worldwide [32-34]. This phenomenon is of great concern since infant and juvenile obesity are significantly correlated with an increased risk of suffering health problems in adulthood, including cardiovascular diseases, hypertension, and obesity [35, 36]. Based on multiple epidemiological studies, it is now clear that environmental factors acting early in life, including nutrition, play an important role in the pathogenesis of diseases in adulthood, particularly in obesity development [37-39]. Interestingly, both overnutrition and undernutrition during pregnancy and lactation are reported to induce long-lasting effects on energy balance and predispose the offspring to incurring metabolic diseases in adulthood [40-42].

Barker and colleagues in their hypothesis "developmental origins of health and disease" proposed that an adverse environment in early life can cause disruptions in normal growth and development, increasing the propensity to obesity and other related diseases in adulthood [43]. There is considerable evidence supporting this proposal, such as the representative example of the Dutch famine during the last 6 months of World War II where males born to women exposed to poor nutrition in the first and second terms of pregnancy were more likely to become obese than those whose mothers did not experience poor nutrition during gestation [44, 45]. In support of the Barker hypothesis, it is well established that abnormal fetal growth affects long-term metabolic health [46]. Indeed, high maternal body mass index (BMI) is a risk factor for large-for-gestational-age (LGA) infants, with these children having increased susceptibility to disease throughout life [47]. Maternal obesity 
increases the risk of metabolic complications in children approximately twofold $[46,48]$ and doubles the risk of stillbirth and neonatal death [49]. Likewise, women with poor glycemic control and/or gestational diabetes have a high risk of giving birth to a macrosomic baby that is more likely to develop obesity and insulin resistance later in life [50,51].

Not only is the prenatal environment important but also the immediate postnatal period since critical windows of organ development extend into early postnatal life. For example, in rodents, pancreatic islets and brain circuits continue their development after birth [5254]. In humans, the postnatal feeding regime affects infant growth trajectories since weight gain during the first weeks of life is positively associated with later obesity [55]. In addition, an earlier age of adiposity rebound is also associated with a higher risk of obesity later on [56].

Thus, both gestational and early postnatal cues are critical for the development of central and peripheral systems involved in metabolic control, including the hypothalamus and adipose tissue, modulating their responses to metabolic signals and increasing the probability of excess weight gain in adulthood. Moreover, recent evidence suggests that behaviors associated with feeding can also be affected by early nutritional influences.

\section{The Hypothalamus in the Control of Energy Homeostasis}

The hypothalamus plays a key role in the control of energy homeostasis, with special attention being paid to neurons in the ARC as these neurons express receptors for circulating hormones involved in appetite regulation and energy expenditure such as leptin, insulin, or ghrelin [57]. In the ARC, orexigenic neurons expressing NPY and AgRP are activated by appetite-stimulating signals such as ghrelin to promote food intake [58]. Another population of neurons express POMC and CART and are activated by anorexigenic signals such as leptin or insulin to promote appetite inhibition and weight loss [59]. Both NPY/AgRP and POMC/CART neurons extend projections to other key parts of the hypothalamus including the paraventricular (PVN), ventromedial (VMH) and dorsomedial (DMH) nuclei and the lateral hypothalamus (LHA), with these regions also participating in food intake regulation [57, 59]. Extrahypothalamic brain areas involved in the regulation of feeding and energy balance include the ventral tegmental area (VTA) and the nucleus of tractus solitarius (NTS) which receive signals from the gastrointestinal system through the dorsal vagal complex.

There are also behavioral aspects of feeding that must be taken into consideration, as some inputs are based on the palatability and reward of food that can override the satiety signals. These hedonic neurocircuits include the nucleus accumbens (NAc), the ventral pallidus (VP), the VTA, and higher cortical areas such as the prefrontal cortex, all of which converge on the LHA. These pathways use biological substrates such as glutamate, opioids, endocannabinoids, and dopamine and are responsive to peripheral metabolic signals like leptin $[60,61]$ and ghrelin $[62,63]$. The effects of these compounds on mood highly contribute to the impact of the hedonic pathways in food intake.

\section{Hypothalamic Development}

Hypothalamic development differs between species. Whereas in nonhuman primates this process is thought to occur entirely during the third trimester of pregnancy $[64,65]$, in rodents it begins prenatally but does not finalize until the second week of postnatal life [66]. In rodents, development of hypothalamic nuclei begins around embryonic day (E) 12 
with neurogenesis in the neuroepithelium of the third ventricle. Once generated, the postmitotic neurons migrate from the proliferative zone of the third ventricle to form the various nuclei and areas that constitute the hypothalamus $[52,67,68]$. The neurons from the different hypothalamic areas are created at different time points, with neurons of the PVN appearing around E 12 and those of other nuclei such as the ARC being born between E 12 and E 16. Neurons in the ARC express POMC around E 12 [69] and NPY around E 14 [70]. The expression of both orexigenic and anorexigenic neuropeptides continues to increase during the postnatal period, reaching their maximum values around postnatal day (PND) 15 [71]. Although neurogenesis occurs prenatally, the establishment of connections between neurons in the different nuclei takes place postnatally, with innervation between neurons of the ARC and DMH being established at PND 6 and between neurons of the ARC and PVN and LH occurring at PND 10 and PND 12, respectively [72]. Since projections from the DMH and VMH develop prior to those from the ARC [72], it is suggested that these neural pathways could be the primary regulators of feeding and metabolism during early postnatal life [67].

\section{Leptin's Impact on Hypothalamic Development}

Apart from its actions in the control of energy homeostasis in adult life, leptin plays an important role in brain development and specifically in the establishment of hypothalamic circuitry [73]. Indeed, leptin-deficient $o b / o b$ mice show several brain disruptions such as reduced brain weight, structural abnormalities, and impaired myelination $[74,75]$ as well as a reduction in cell density and synaptic and glial proteins in various brain regions, including the hypothalamus [76]. These mice also have modifications in the number of projections and synaptic inputs to hypothalamic areas and neuronal populations that control metabolism $[21,77]$.

Leptin can restore normal brain weight in $o b / o b$ mice only when this hormone is injected during early life [78], suggesting that specific critical periods exist for its developmental actions. Indeed, Bouret et al. [77] demonstrated that leptin has a powerful trophic action in the brain, increasing the density and length of axons from ARC neurons in vitro, and that leptin treatment to ob/ob animals only restored the abnormalities in ARC projections when it was administered during the first days of postnatal life, and not in adulthood.

In 1998 Ahima et al. [79] reported that there is a postnatal leptin surge in rodents, with leptin levels increasing around PND5 and peaking between PND 9 and PND 10. However, these increased leptin levels were not related to increased fat mass although a transient upregulation of leptin mRNA was found in adipose tissue during this period [79]. In sheep this peak occurs between PND 6 and PND 9 [80], and in humans leptin levels decrease after birth [81].

The characteristics of the leptin peak can be modified by both the prenatal and postnatal nutritional environment. Both maternal under- and overnutrition are reported to increase the leptin surge in the offspring $[82,83]$ while the postnatal rise in leptin does not occur in lambs born to obese mothers [80]. However, all of these scenarios result in increased weight in the offspring during later stages of life.

Although the leptin receptor is expressed and functional during neonatal life [84, 85], leptin is unable to modulate feeding or energy expenditure until the second postnatal week [86]. Thus, during this period leptin seems to be more involved in hypothalamic development than in the regulation of body weight and food intake.

The fact that leptin levels are elevated during embryonic development in humans [87], particularly during the third trimester of pregnancy $[65,88]$, and the observation that leptin 


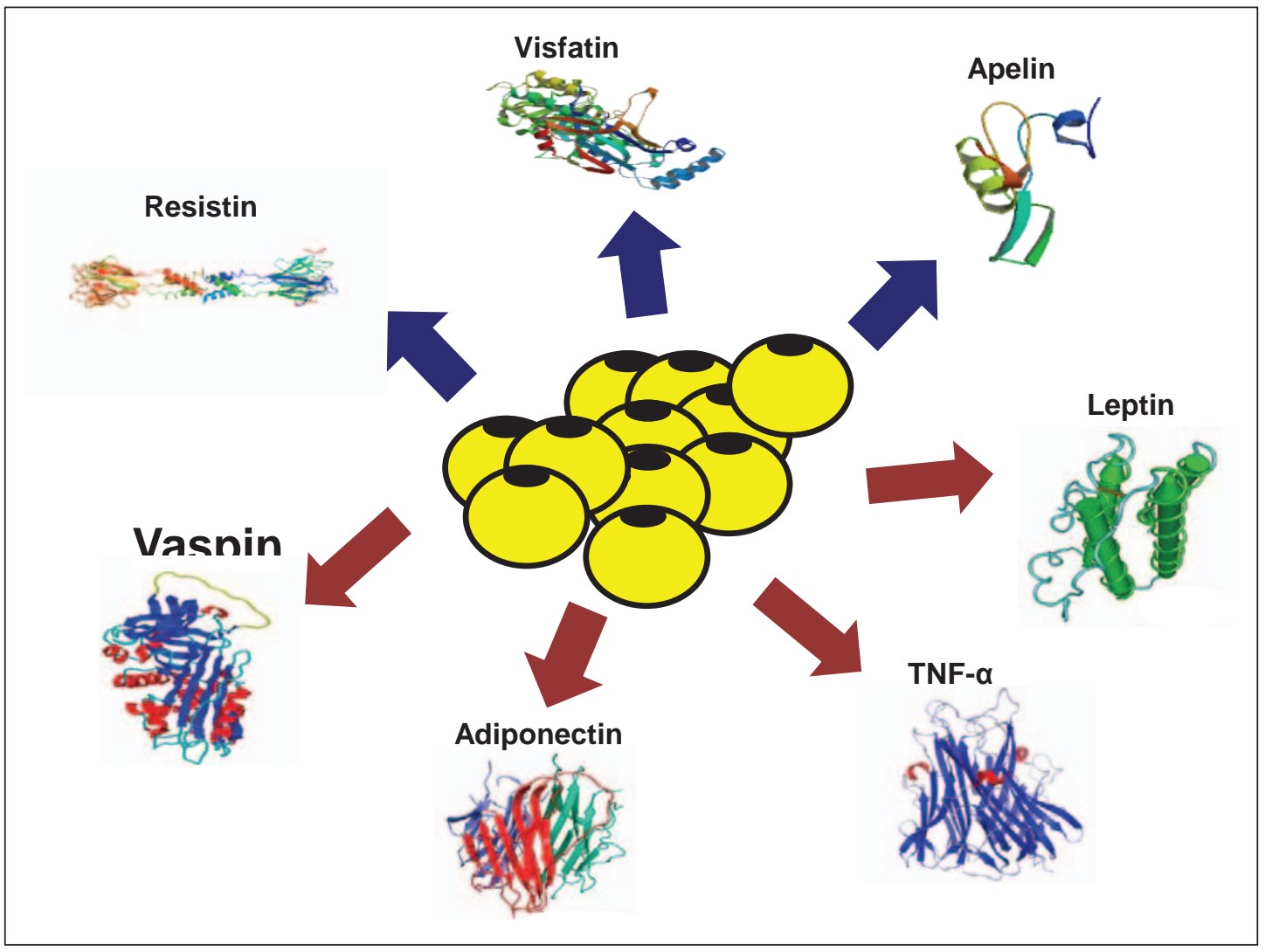

Fig. 2. Adipocytes secrete different adipokines such as leptin, visfatin, resistin, apelin, TNF- $\alpha$ and adiponectin among others.

levels at birth are correlated with head circumference [89] supports the hypothesis that leptin also influences brain development in humans. In addition, leptin-deficient patients show modifications in different brain structures [90-92]. These changes are anatomically specific, with leptin administration exerting sustained effects on neural tissue composition.

Moreover, modifications in leptin levels during development also induce long-term effects in some leptin-modulated behaviors. Fraga-Marques et al. [93] reported that increased neonatal leptin levels program anxiety-like behaviors, but not memory in rats. In humans with congenital leptin deficiency, leptin replacement modifies brain activity in areas associated with emotions, including hunger and reward in response to food-related stimuli $[90,94,95]$. Likewise, in mice neonatal leptin treatment has been recently shown to have long-term effects on behavior and brain anatomy [96].

\section{Adipose Tissue Development}

Adipose tissue has been historically considered as an inert organ with little influence on physiology apart from its role as a storage depot for excess energy. However, in recent years much evidence has highlighted it as a dynamic participant in regulating whole-body metabolism. In fact, changes in the distribution, structure, and function of adipose tissue dramatically influence the ability of an individual to maintain energy balance and resist weight gain [97, 98] (fig. 2). 


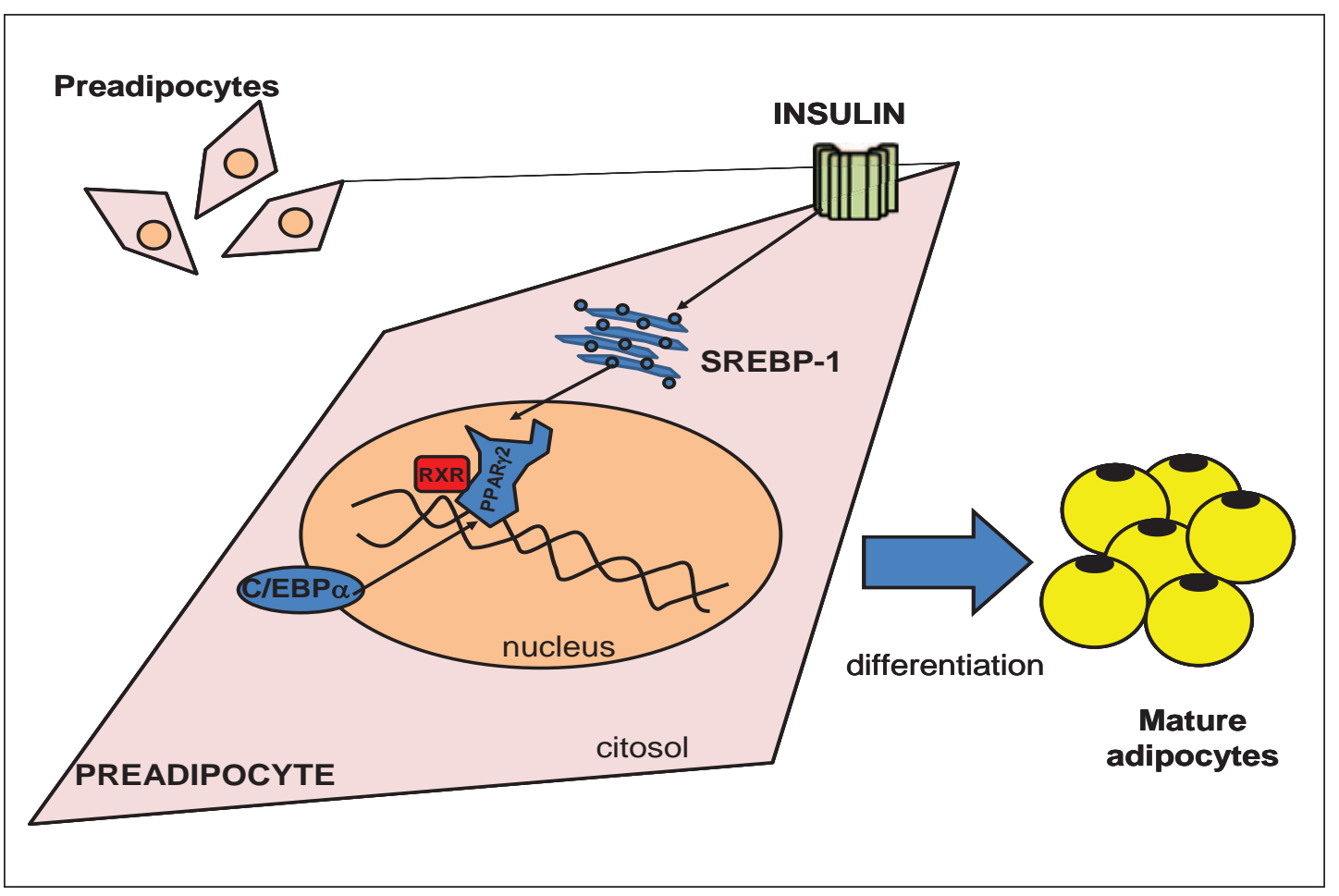

Fig. 3. Adipogenesis is regulated by peroxisome proliferator-activated receptor $\gamma(\operatorname{PPAR} \gamma)$ that is activated by CAAT enhancer binding proteins (C/EBPs) and regulatory element-binding protein 1 (SREBP-1). Different factors can initiate the differentiation process, with insulin being and indispensable factor for the formation of mature adipocytes.

In humans adipogenesis occurs primarily during late fetal and early postnatal life although it can also be stimulated in adulthood under certain conditions like obesity [99, 100]. The first traces of adipose tissue are detectable between the 14th and 16th week of human gestation [101]. Some of the key regulators identified in the adipogenic process include peroxisome proliferator-activated receptors (PPARs), CAAT enhancer binding proteins (C/EBPs) and sterol regulatory element-binding protein (SREBP-1) [102], which are expressed early in immature adipocytes. These transcription factors operate synergistically, regulating the expression of other adipocyte-specific genes and resulting in the formation of mature adipocytes with capacity for lipid storage, lipid degradation, and adipokine secretion [103] (fig. 3).

From the beginning of adipogenesis until the 23rd week of prenatal life, the number of fat lobules remains constant, with the size of the lobules growing in subsequent weeks and acquiring the typical multilocular morphology of adipocytes [101, 104, 105]. Around the third trimester, small adipocytes can be found in the main sites of fat deposition, with body fat accounting for approximately $16 \%$ of body weight at birth. During the first 12 months of postnatal life the increase in body fat is due to an increase in fat cell size, while adipocyte numbers remain unchanged $[105,106]$. However, it has been reported that both changes in adipocyte volume and number can also occur at later stages of life under certain conditions like obesity [100]. 


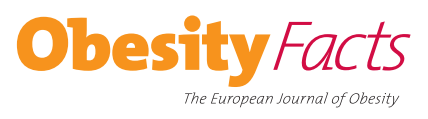

\section{Leptin's Impact on Adipose Tissue Development}

During early life, adipocyte proliferation and differentiation are highly sensitive to the nutritional environment, in particular to the concentrations of circulating hormones and nutrients such as insulin-like growth factors, glucose, insulin, and glucocorticoids [107, 108]. Nutrient availability during this period is reported to determine fat mass in adulthood since overfeeding during the first weeks of life induces an overexpansion of adipose tissue in rats which is associated with an increase in the number of fat cells [109-111], whereas undernutrition permanently reduces adipose cell number [112]. Studies in sheep and pigs also show that exposure to excess nutrients during late gestation significantly increases fat mass, adipocyte size, and the capacity of fat cells for storing lipids in postnatal life [113]. Some of these nutrition-induced changes may be mediated through modifications in leptin levels.

In the fetus, leptin levels follow the evolution of adipose tissue development, with low levels being found during the first half of gestation and dramatically increasing during the last part of the third trimester $[87,114]$. Shortly after birth, circulating leptin levels decline [81]. The conversion of preadipocytes into mature adipocytes is accompanied by an increase in leptin gene expression [115], and abundance of leptin in fetal adipose tissue is related to fetal body weight [116]. Indeed, children born small for gestational age have lower cord blood leptin levels than those born normal for gestational age [117]. Leptin levels in cord blood have been suggested to predict adiposity in later years [118], suggesting that in utero leptin levels also have long-term influences on metabolism in humans.

Since leptin is produced by the placenta and is also found in breast milk [119], maternal leptin levels during pregnancy and lactation may have an impact on adipose tissue development in the offspring. Studies show that diet-induced hyperleptinemia in the mother results in increased body weight and adiposity in the offspring [53, 120]. However, in addition to hyperleptinemia, obesity is associated with many other alterations; so it is difficult to determine the exact influence of leptin from overweight mothers on the increased adiposity of their offspring.

Controversial results have been obtained regarding maternal leptin administration during pregnancy. In lean rats, maternal leptin treatment during the first 10 days of lactation results in increased food intake and body weight gain as well as in increased visceral fat, leptin resistance, hyperglycemia, and hyperleptinemia in the offspring, with these alterations becoming evident after puberty and aggravating with age [121]. In contrast, leptin treatment of pregnant rats during the last week of gestation prevents the diet-induced increase in body and fat pad weights when the offspring are later exposed to a high-fat diet [122]. In sheep, maternal leptin infusion until the end of gestation altered adipose tissue morphology, increasing the number of multilocular adipocytes and the expression of UCP-1 [123].

The effect of leptin administration during the postnatal period is far from being clear since it has been reported to both protect [124] and predispose [125] to obesity later in life. The nutritional status of the mother seems to play a key role in the offspring's response to postnatal leptin administration [126]. The controversial effects could also be explained by differences in the dosages used, the routes of administration, the treatment duration, or the different time points of leptin administration. Indeed, recent data from our laboratory indicate that not only are leptin levels important in the suckling period for the development of metabolic systems but also the exact moment in which they are modified. We found that acute hyperleptinemia on PND 2 reduces food intake in the adult offspring without affecting body weight gain, whereas blunting leptin levels on PND 9 decreases adiposity at adulthood without affecting food intake [127]. 
Prolonged neonatal hypoleptinemia also has delayed effects on metabolism. Blunting the postnatal leptin surge from PND 2 to PND 13 results in long-term leptin insensitivity and increased susceptibility to diet-induced obesity [128]. In addition, maternal deprivationinduced hypoleptinemia decreases body weight and leptin levels in adult rats [129-130].

In conclusion, leptin levels during early life are important for the development of the adult metabolic profile as they affect the development of central and peripheral systems involved in energy homeostasis. Moreover, it is clear that modulation of the levels of this important hormone during development, whether increased or decreased, acutely or chronically, can have diverse effects on these systems. Further elucidation of this phenomenon and the mechanisms involved may help us to understand the recent and dramatic rise in obesity in many countries and to develop a strategy for its prevention.

\section{Disclosure Statement}

The authors declared no conflict of interest.

\section{References}

1 Zhang Y, Proenca R, Maffei M, Barone M, Leopold L, Friedman JM: Positional cloning of the mouse obese gene and its human homologue. Nature 1994;372:425-432.

- 2 Schwartz MW, Peskind E, Raskind M, Boyko EJ, Porte D: Cerebrospinal fluid leptin levels: relationship to plasma levels and to adiposity in humans. Nat Med 1996;2:589-593.

- 3 Friedman JM, Halaas JL: Leptin and the regulation of body weight in mammals. Nature 1998;395:763-770.

- 4 Considine RV, Sinha MK, Heiman ML, Kriauciunas A, Stephens TW, Nyce MR, Ohannesian JP, Marco CC, McKee LJ, Bauer TL: Serum immunoreactive-leptin concentrations in normal-weight and obese humans. N Engl J Med 1996;334:292-295.

5 Maffei M, Halaas J, Ravussin E, Pratley RE, Lee GH, Zhang Y, Fei H, Kim S, Lallone R, Ranganathan S: Leptin levels in human and rodent: measurement of plasma leptin and ob RNA in obese and weight-reduced subjects. Nat Med 1995;1:1155-1161.

- 6 Baumann H, Morella KK, White DW, Dembski M, Bailon PS, Kim H, Lai CF, Tartaglia LA: The full-length leptin receptor has signaling capabilities of interleukin 6-type cytokine receptors. Proc Natl Acad Sci U S A 1996; 93:8374-8378.

7 Lee GH, Proenca R, Montez JM, Carroll KM, Darvishzadeh JG, Lee JI, Friedman JM: Abnormal splicing of the leptin receptor in diabetic mice. Nature 1996;379:632-635.

- 8 Kratzsch J, Lammert A, Bottner A, Seidel B, Mueller G, Thiery J, Hebebrand J, Kiess W: Circulating soluble leptin receptor and free leptin index during childhood, puberty, and adolescence. J Clin Endocrinol Metab 2002;87:4587-4594.

- 9 Smith JT, Mark PJ, Waddell BJ: Developmental increases in plasma leptin binding activity and tissue Ob-Re mRNA expression in the rat. J Endocrinol 2005;184:535-541.

10 Håkansson ML, Meister B: Transcription factor STAT3 in leptin target neurons of the rat hypothalamus. Neuroendocrinology 1998;68:420-427.

11 Chua SC, Chung WK, Wu-Peng XS, Zhang Y, Liu SM, Tartaglia L, Leibel RL: Phenotypes of mouse diabetes and rat fatty due to mutations in the ob (leptin) receptor. Science 1996;271:994-996.

12 Bjørbaek C, El-Haschimi K, Frantz JD, Flier JS: The role of SOCS-3 in leptin signaling and leptin resistance. J Biol Chem 1999;274:30059-30065.

-13 Münzberg H, Flier JS, Bjørbaek C: Region-specific leptin resistance within the hypothalamus of diet-induced obese mice. Endocrinology 2004;145:4880-4889.

14 Cook WS, Unger RH: Protein tyrosine phosphatase 1b: a potential leptin resistance factor of obesity. Dev Cell 2002;2:385-387.

-15 Zabolotny JM, Bence-Hanulec KK, Stricker-Krongrad A, Haj F, Wang Y, Minokoshi Y, Kim Y-B, Elmquist JK, Tartaglia LA, Kahn BB, Neel BG: Ptp1b regulates leptin signal transduction in vivo. Dev Cell 2002;2:489495.

16 Kaszubska W, Falls HD, Schaefer VG, Haasch D, Frost L, Hessler P, Kroeger PE, White DW, Jirousek MR, Trevillyan JM: Protein tyrosine phosphatase $1 \mathrm{~b}$ negatively regulates leptin signaling in a hypothalamic cell line. Mol Cell Endocrinol 2002;195:109-118. 
Elchebly M, Payette P, Michaliszyn E, Cromlish W, Collins S, Loy AL, Normandin D, Cheng A, Himms-Hagen J, Chan CC, Ramachandran C, Gresser MJ, Tremblay ML, Kennedy BP: Increased insulin sensitivity and obesity resistance in mice lacking the protein tyrosine phosphatase-1b gene. Science 1999;283:15441548.

18 Klaman LD, Boss O, Peroni OD, Kim JK, Martino JL, Zabolotny JM, Moghal N, Lubkin M, Kim YB, Sharpe AH, Stricker-Krongrad A, Shulman GI, Neel BG, Kahn BB: Increased energy expenditure, decreased adiposity, and tissue-specific insulin sensitivity in protein-tyrosine phosphatase 1b-deficient mice. Mol Cell Biol 2000;20:5479-5489.

19 Niswender KD, Morton GJ, Stearns WH, Rhodes CJ, Myers MG, Schwartz MW: Intracellular signalling. Key enzyme in leptin-induced anorexia. Nature 2001;413:794-795.

20 Zhao AZ, Huan J-N, Gupta S, Pal R, Sahu A: A phosphatidylinositol 3-kinase phosphodiesterase 3b-cyclic AMP pathway in hypothalamic action of leptin on feeding. Nat Neurosci 2002;5:727-728.

-21 Pinto S, Roseberry AG, Liu H, Diano S, Shanabrough M, Cai X, Friedman JM, Horvath TL: Rapid rewiring of arcuate nucleus feeding circuits by leptin. Science 2004;304:110-115.

-22 Garcia-Caceres C, Fuente-Martin E, Burgos-Ramos E, Granado M, Frago LM, Barrios V, Horvath T, Argente J, Chowen JA: Differential acute and chronic effects of leptin on hypothalamic astrocyte morphology and synaptic protein levels. Endocrinology 2011;152:1809-1818.

-23 Kawai K, Sugimoto K, Nakashima K, Miura H, Ninomiya Y: Leptin as a modulator of sweet taste sensitivities in mice. Proc Natl Acad Sci U S A 2000;97:11044-11049.

-24 Elmquist JK, Bjorbaek C, Ahima RS, Flier JS, Saper CB: Distributions of leptin receptor mRNA isoforms in the rat brain. J Comp Neurol 1998;395:535-547.

25 Figlewicz DP, Evans SB, Murphy J, Hoen M, Baskin DG: Expression of receptors for insulin and leptin in the ventral tegmental area/substantia nigra (VTA/SN) of the rat. Brain Res 2003;964:107-115.

-26 Hay-Schmidt A, Helboe L, Larsen PJ: Leptin receptor immunoreactivity is present in ascending serotonergic and catecholaminergic neurons of the rat. Neuroendocrinology 2001;73:215-226.

27 Asakawa A, Inui A, Inui T, Katsuura G, Fujino MA, Kasuga M: Leptin treatment ameliorates anxiety in ob/ ob obese mice. J Diabetes Complications 2003;17:105-107.

28 Figlewicz DP, MacDonald Naleid A, Sipols AJ: Modulation of food reward by adiposity signals. Physiol Behav 2007;91:473-478. Fulton S, Woodside B, Shizgal P: Modulation of brain reward circuitry by leptin. Science 2000;287:125-128. Domura Y, Hori N, Shiraishi T, Fukunaga K, Takeda H, Tsuji M, Matsumiya T, Ishibashi M, Aou S, Li XL, Kohno D, Uramura K, Sougawa H, Yada T, Wayner MJ, Sasaki K: Leptin facilitates learning and memory performance and enhances hippocampal CA1 long-term potentiation and CaMK II phosphorylation in rats. Peptides 2006;27:2738-2749.

-31 Reidy SP, Weber J: Leptin: AN essential regulator of lipid metabolism. Comp Biochem Physiol A Mol Integr Physiol 2000;125:285-298.

-32 Goran MI, Treuth MS: Energy expenditure, physical activity, and obesity in children. Pediatr Clin North Am 2001;48:931-953.

-33 Gordon FK, Ferguson EL, Toafa V, Henry T-E, Goulding A, Grant AM, Guthrie BE: High levels of childhood obesity observed among 3- to 7-year-old New Zealand pacific children is a public health concern. J Nutr 2003;133:3456-3460.

-34 Ogden CL, Flegal KM, Carroll MD, Johnson CL: Prevalence and trends in overweight among us children and adolescents, 1999-2000. JAMA 2002;288:1728-1732.

-35 Caprio S, Tamborlane WV: Metabolic impact of obesity in childhood. Endocrinol Metab Clin North Am 1999; 28:731-747.

-36 Dietz WH: Critical periods in childhood for the development of obesity. Am J Clin Nutr 1994;59:955-959. McMillen IC, Robinson JS: Developmental origins of the metabolic syndrome: prediction, plasticity, and programming. Physiol Rev 2005;85:571-633.

38 Robillard JE, Segar JL: Influence of early life events on health and diseases. Trans Am Clin Climatol Assoc 2006;117:313-319; discussion 319-320.

39 Sallout B, Walker M: The fetal origin of adult diseases. J Obstet Gynaecol 2003;23:555-560.

$\$ 40$ Levin BE: Metabolic imprinting: critical impact of the perinatal environment on the regulation of energy homeostasis. Philos Trans R Soc Lond B Biol Sci 2006;361:1107-1121.

-41 Plagemann A: Perinatal nutrition and hormone-dependent programming of food intake. Horm Res 2006; 65(suppl 3):83-89.

42 Sullivan EL, Grove KL: Metabolic imprinting in obesity. Forum Nutr 2010;63:186-194.

43 Barker DJP: Obesity and early life. Obes Rev 2007;8(suppl 1):45-49.

44 Ravelli AC, van Der Meulen JH, Osmond C, Barker DJ, Bleker OP: Obesity at the age of $50 \mathrm{y}$ in men and women exposed to famine prenatally. Am J Clin Nutr 1999;70:811-816.

45 Ravelli GP, Stein ZA, Susser MW: Obesity in young men after famine exposure in utero and early infancy. N Engl J Med 1976;295:349-353.

-46 Dietz WH: Periods of risk in childhood for the development of adult obesity - what do we need to learn? J Nutr 1997;127:1884S-1886S.

47 Ehrenberg HM, Mercer BM, Catalano PM: The influence of obesity and diabetes on the prevalence of macrosomia. Am J Obstet Gynecol 2004;191:964-968. 
-48 Wei J-N, Sung F-C, Li C-Y, Chang C-H, Lin R-S, Lin C-C, Chiang C-C, Chuang L-M: Low birth weight and high birth weight infants are both at an increased risk to have type 2 diabetes among schoolchildren in Taiwan. Diabetes Care 2003;26:343-348.

49 Wisborg K, Vesterggard M, Kristensen J, Kesmodel U: Prepregnancy body mass index and sudden infant death syndrome. Epidemiology 2003;14:630.

50 Gillman MW, Rifas-Shiman S, Berkey CS, Field AE, Colditz GA: Maternal gestational diabetes, birth weight, and adolescent obesity. Pediatrics 2003;111:e221-e226.

51 Plagemann A, Harder T, Kohlhoff R, Rohde W, Dörner G: Overweight and obesity in infants of mothers with long-term insulin-dependent diabetes or gestational diabetes. Int J Obes Relat Metab Disord 1997;21:451456.

52 Bouret SG, Simerly RB: Minireview: leptin and development of hypothalamic feeding circuits. Endocrinology 2004;145:2621-2626.

53 Grove KL, Grayson BE, Glavas MM, Xiao XQ, Smith MS: Development of metabolic systems. Physiol Behav 2005;86:646-660.

54 Kaung HL: Growth dynamics of pancreatic islet cell populations during fetal and neonatal development of the rat. Dev Dyn 1994;200:163-175.

55 Stettler N, Stallings VA, Troxel AB, Zhao J, Schinnar R, Nelson SE, Ziegler EE, Strom BL: Weight gain in the first week of life and overweight in adulthood: a cohort study of European American subjects fed infant formula. Circulation 2005;111:1897-1903.

56 Taylor RW, Grant AM, Goulding A, Williams SM: Early adiposity rebound: review of papers linking this to subsequent obesity in children and adults. Curr Opin Clin Nutr Metab Care 2005;8:607-612.

57 Elmquist JK, Coppari R, Balthasar N, Ichinose M, Lowell BB: Identifying hypothalamic pathways controlling food intake, body weight, and glucose homeostasis. J Comp Neurol 2005;493:63-71.

58 Kamegai J, Tamura H, Shimizu T, Ishii S, Sugihara H, Wakabayashi I: Chronic central infusion of ghrelin increases hypothalamic neuropeptide $Y$ and agouti-related protein mRNA levels and body weight in rats. Diabetes 2001;50:2438-2443.

-59 Schwartz MW, Woods SC, Porte D, Seeley RJ, Baskin DG: Central nervous system control of food intake. Nature 2000;404:661-671.

60 Cota D, Barrera JG, Seeley RJ: Leptin in energy balance and reward: two faces of the same coin? Neuron 2006;51:678-680.

61 Szczypka MS, Rainey MA, Palmiter RD: Dopamine is required for hyperphagia in lep(ob/ob) mice. Nat Genet 2000;25:102-104.

62 Abizaid A, Liu Z-W, Andrews ZB, Shanabrough M, Borok E, Elsworth JD, Roth RH, Sleeman MW, Picciotto MR, Tschöp MH, Gao X-B, Horvath TL: Ghrelin modulates the activity and synaptic input organization of midbrain dopamine neurons while promoting appetite. J Clin Invest 2006;116:3229-3239.

63 Brunetti L, Recinella L, Orlando G, Michelotto B, Nisio CD, Vacca M: Effects of ghrelin and amylin on dopamine, norepinephrine and serotonin release in the hypothalamus. Eur J Pharmacol 2002;454:189192.

64 Grayson BE, Allen SE, Billes SK, Williams SM, Smith MS, Grove KL: Prenatal development of hypothalamic neuropeptide systems in the nonhuman primate. Neuroscience 2006;143:975-986.

65 Koutcherov Y, Mai JK, Paxinos G: Hypothalamus of the human fetus. J Chem Neuroanat 2003;26:253-270.

66 Bouret SG, Simerly RB: Developmental programming of hypothalamic feeding circuits. Clin Genet 2006;70: 295-301.

67 Bouret SG: Leptin, nutrition, and the programming of hypothalamic feeding circuits. Nestle Nutr Workshop Ser Pediatr Program 2010;65:25-35; discussion 35-29.

68 Simerly RB: Hypothalamic substrates of metabolic imprinting. Physiol Behav 2008;94:79-89.

69 Khachaturian H, Alessi NE, Lewis ME, Munfakh N, Fitzsimmons MD, Watson SJ: Development of hypothalamic opioid neurons: A combined immunocytochemical and [3h]thymidine autoradiographic study. Neuropeptides 1985;5:477-480.

-70 Kagotani Y, Hashimoto T, Tsuruo Y, Kawano H, Daikoku S, Chihara K: Development of the neuronal system containing neuropeptide $Y$ in the rat hypothalamus. Int J Dev Neurosci 1989;7:359-374.

71 Cottrell EC, Cripps RL, Duncan JS, Barrett P, Mercer JG, Herwig A, Ozanne SE: Developmental changes in hypothalamic leptin receptor: Relationship with the postnatal leptin surge and energy balance neuropeptides in the postnatal rat. Am J Physiol Regul Integr Comp Physiol 2009;296:R631-R639.

$\checkmark 72$ Bouret SG, Draper SJ, Simerly RB: Formation of projection pathways from the arcuate nucleus of the hypothalamus to hypothalamic regions implicated in the neural control of feeding behavior in mice. J Neurosci 2004;24:2797-2805.

73 Bouret SG: Neurodevelopmental actions of leptin. Brain Res 2010;1350:2-9.

74 Bereiter DA, Jeanrenaud B: Altered neuroanatomical organization in the central nervous system of the genetically obese (ob/ob) mouse. Brain Res 1979;165:249-260.

75 Sena A, Sarliève LL, Rebel G: Brain myelin of genetically obese mice. J Neurol Sci 1985;68:233-243.

-76 Ahima RS, Bjorbaek C, Osei S, Flier JS: Regulation of neuronal and glial proteins by leptin: implications for brain development. Endocrinology 1999;140:2755-2762.

77 Bouret SG, Draper SJ, Simerly RB: Trophic action of leptin on hypothalamic neurons that regulate feeding. Science 2004;304:108-110. 
Steppan CM, Swick AG: A role for leptin in brain development. Biochem Biophys Res Commun 1999;256: 600-602.

-79 Ahima RS, Prabakaran D, Flier JS: Postnatal leptin surge and regulation of circadian rhythm of leptin by feeding. Implications for energy homeostasis and neuroendocrine function. J Clin Invest 1998;101:10201027.

$\checkmark 80$ Long NM, Ford SP, Nathanielsz PW: Maternal obesity eliminates the neonatal lamb plasma leptin peak. J Physiol 2011;589:1455-1462.

81 Marinoni E, Corona G, Ciardo F, Letizia C, Moscarini M, Di Iorio R: Changes in the interrelationship between leptin, resistin and adiponectin in early neonatal life. Front Biosci (Elite Ed) 2010;2:52-58.

$>82$ Kirk SL, Samuelsson AM, Argenton M, Dhonye H, Kalamatianos T, Poston L, Taylor PD, Coen CW: Maternal obesity induced by diet in rats permanently influences central processes regulating food intake in offspring. PLoS One 2009; 4:e5870.

-83 Yura S, Itoh H, Sagawa N, Yamamoto H, Masuzaki H, Nakao K, Kawamura M, Takemura M, Kakui K, Ogawa Y, Fujii S: Role of premature leptin surge in obesity resulting from intrauterine undernutrition. Cell Metab 2005;1:371-378.

84 Matsuda J, Yokota I, Tsuruo Y, Murakami T, Ishimura K, Shima K, Kuroda Y: Development changes in longform leptin receptor expression and localization in rat brain. Endocrinology 1999;140:5233-5238.

-85 Proulx K, Richard D, Walker C-D: Leptin regulates appetite-related neuropeptides in the hypothalamus of developing rats without affecting food intake. Endocrinology 2002;143:4683-4692.

-86 Mistry AM, Swick A, Romsos DR: Leptin alters metabolic rates before acquisition of its anorectic effect in developing neonatal mice. Am J Physiol 1999;277:R742-R747.

87 Jaquet D, Leger J, Levy-Marchal C, Oury JF, Czernichow P: Ontogeny of leptin in human fetuses and newborns: effect of intrauterine growth retardation on serum leptin concentrations. J Clin Endocrinol Metab 1998;83: 1243-1246.

88 Koutcherov Y, Mai JK, Ashwell KWS, Paxinos G: Organization of human hy pothalamus in fetal development. J Comp Neurol 2002;446:301-324.

89 Gohlke BC, Huber A, Bartmann P, Fimmers R, Hecher K, Bouret SG, Roth CL: Cord blood leptin and IGF-I in relation to birth weight differences and head circumference in monozygotic twins. J Pediatr Endocrinol Metab 2006;19:3-9.

$\checkmark 90$ Frank S, Heni M, Moss A, von Schnurbein J, Fritsche A, Haring HU, Farooqi S, Preissl H, Wabitsch M: Leptin therapy in a congenital leptin-deficient patient leads to acute and long-term changes in homeostatic, reward, and food-related brain areas. J Clin Endocrinol Metab 2011;96:E1283-1287.

$\checkmark 91$ London ED, Berman SM, Chakrapani S, Delibasi T, Monterosso J, Erol HK, Paz-Filho G, Wong M-L, Licinio J: Short-term plasticity of gray matter associated with leptin deficiency and replacement. J Clin Endocrinol Metab 2011;96:E1212-1220. Erratum in J Clin Endocrinol Metab 2011;96:3576.

$\$ 92$ Matochik JA, London ED, Yildiz BO, Ozata M, Caglayan S, DePaoli AM, Wong ML, Licinio J: Effect of leptin replacement on brain structure in genetically leptin-deficient adults. J Clin Endocrinol Metab 2005;90: 2851-2854.

93 Fraga-Marques MC, Moura EG, Claudio-Neto S, Trevenzoli IH, Toste FP, Passos MC, Lisboa PC, Manhaes AC: Neonatal hyperleptinaemia programmes anxiety-like and novelty seeking behaviours but not memory/ learning in adult rats. Horm Behav 2009;55:272-279.

$\$ 94$ Baicy K, London ED, Monterosso J, Wong ML, Delibasi T, Sharma A, Licinio J: Leptin replacement alters brain response to food cues in genetically leptin-deficient adults. Proc Natl Acad Sci U S A 2007;104:1827618279.

-95 Farooqi IS, Bullmore E, Keogh J, Gillard J, 0’Rahilly S, Fletcher PC: Leptin regulates striatal regions and human eating behavior. Science 2007;317:1355.

-96 Erkonen GE, Hermann GM, Miller RL, Thedens DL, Nopoulos PC, Wemmie JA, Roghair RD: Neonatal leptin administration alters regional brain volumes and blocks neonatal growth restriction-induced behavioral and cardiovascular dysfunction in male mice. Pediatr Res 2011;69:406-412.

$\$ 97$ Björntorp P: Adipose tissue distribution and function. Int J Obes 1991;15(suppl 2):67-81.

$\$ 98$ Galic S, Oakhill JS, Steinberg GR: Adipose tissue as an endocrine organ. Mol Cell Endocrinol 2010;316:129_ 139.

99 Faust IM, Johnson PR, Stern JS, Hirsch J: Diet-induced adipocyte number increase in adult rats: a new model of obesity. Am J Physiol 1978;235:E279-E286.

100 Prins JB, O’Rahilly S: Regulation of adipose cell number in man. Clin Sci (Lond) 1997;92:3-11.

101 Poissonnet CM, Burdi AR, Garn SM: The chronology of adipose tissue appearance and distribution in the human fetus. Early Hum Dev 1984;10:1-11.

102 Rosen ED, Walkey CJ, Puigserver P, Spiegelman BM: Transcriptional regulation of adipogenesis. Genes Dev 2000;14:1293-1307.

103 Hwang CS, Loftus TM, Mandrup S, Lane MD: Adipocyte differentiation and leptin expression. Annu Rev Cell Dev Biol 1997;13:231-259.

104 Niemelä S-M, Miettinen S, Konttinen Y, Waris T, Kellomäki M, Ashammakhi NA, Ylikomi T: Fat tissue: views on reconstruction and exploitation. J Craniofac Surg 2007;18:325-335.

105 Kiess W, Petzold S, Töpfer M, Garten A, Blüher S, Kapellen T, Körner A, Kratzsch J: Adipocytes and adipose tissue. Best Pract Res Clin Endocrinol Metab 2008;22:135-153. 
-106 Spalding KL, Arner E, Westermark PO, Bernard S, Buchholz BA, Bergmann O, Blomqvist L, Hoffstedt J, Näslund E, Britton T, Concha H, Hassan M, Rydén M, Frisén J, Arner P: Dynamics of fat cell turnover in humans. Nature 2008;453:783-787.

107 Ailhaud G, Grimaldi P, Négrel R: Cellular and molecular aspects of adipose tissue development. Annu Rev Nutr 1992;12:207-233.

108 Martin RJ, Hausman GJ, Hausman DB: Regulation of adipose cell development in utero. Proc Soc Exp Biol Med 1998;219:200-210.

109 Bassett DR, Craig BW: Influence of early nutrition on growth and adipose tissue characteristics in male and female rats. J Appl Physiol 1988;64:1249-1256.

110 Hirsch J, Han PW: Cellularity of rat adipose tissue: effects of growth, starvation, and obesity. J Lipid Res 1969;10:77-82.

111 Plagemann A, Harder T, Rake A, Waas T, Melchior K, Ziska T, Rohde W, Dörner G: Observations on the orexigenic hypothalamic neuropeptide Y-system in neonatally overfed weanling rats. J Neuroendocrinol 1999; 11:541-546.

112 Faust IM, Johnson PR, Hirsch J: Long-term effects of early nutritional experience on the development of obesity in the rat. J Nutr 1980;110:2027-2034.

113 Muhlhausler B, Smith SR: Early-life origins of metabolic dysfunction: role of the adipocyte. Trends Endocrinol Metab 2009;20:51-57.

114 Geary M, Herschkovitz R, Pringle PJ, Rodeck CH, Hindmarsh PC: Ontogeny of serum leptin concentrations in the human. Clin Endocrinol (Oxf) 1999;51:189-192.

115 Ye Z-W, Wu X-M, Jiang J-G: Expression changes of angiotensin II pathways and bioactive mediators during human preadipocytes-visceral differentiation. Metabolism 2009;58:1288-1296.

116 Bernard SJ, Yuen I, McMillen C, Symonds ME, Owens PC: Abundance of leptin m $\alpha$ in fetal adipose tissue is related to fetal body weight. J Endocrinol 1999;163:R1-R4.

117 Martos-Moreno GA, Barrios V, Saenz de Pipaon M, Pozo J, Dorronsoro I, Martinez-Biarge M, Quero J, Argente $\mathrm{J}$ : Influence of prematurity and growth restriction on the adipokine profile, igf1, and ghrelin levels in cord blood: relationship with glucose metabolism. Eur J Endocrinol 2009;161:381-389.

118 Mantzoros CS, Rifas-Shiman SL, Williams CJ, Fargnoli JL, Kelesidis T, Gillman MW: Cord blood leptin and adiponectin as predictors of adiposity in children at 3 years of age: a prospective cohort study. Pediatrics 2009;123:682-689.

119 Alexe D-M, Syridou G, Petridou ET: Determinants of early life leptin levels and later life degenerative outcomes. Clin Med Res 2006;4:326-335.

120 Levin BE: Factors promoting and ameliorating the development of obesity. Physiol Behav 2005;86:633639.

121 Pereira-Toste F, Toste FP, Oliveira E, Trotta PA, Lisboa PC, de Moura EG, Passos MCF: Early maternal hyperleptinemia programs adipogenic phenotype in rats. Horm Metab Res 2009;41:874-879.

122 Stocker CJ, Wargent E, O’Dowd J, Cornick C, Speakman JR, Arch JR, Cawthorne MA: Prevention of dietinduced obesity and impaired glucose tolerance in rats following administration of leptin to their mothers. Am J Physiol Regul Integr Comp Physiol 2007;292:R1810-1818.

-123 Yuen BSJ, Owens PC, Muhlhausler BS, Roberts CT, Symonds ME, Keisler DH, McFarlane JR, Kauter KG, Evens Y, McMillen IC: Leptin alters the structural and functional characteristics of adipose tissue before birth. FASEB J 2003;17:1102-1104.

124 Pico C, Oliver P, Sanchez J, Miralles O, Caimari A, Priego T, Palou A: The intake of physiological doses of leptin during lactation in rats prevents obesity in later life. Int J Obes (Lond) 2007;31:1199-1209.

-125 Toste FP, de Moura EG, Lisboa PC, Fagundes AT, de Oliveira E, Passos MCF: Neonatal leptin treatment programmes leptin hypothalamic resistance and intermediary metabolic parameters in adult rats. $\mathrm{Br} \mathrm{J}$ Nutr 2006;95:830-837.

126 Vickers MH, Gluckman PD, Coveny AH, Hofman PL, Cutfield WS, Gertler A, Breier BH, Harris M: The effect of neonatal leptin treatment on postnatal weight gain in male rats is dependent on maternal nutritional status during pregnancy. Endocrinology 2008;149:1906-1913.

127 Granado M, Garcia-Caceres C, Fuente-Martin E, Diaz F, Mela V, Viveros MP, Argente J, Chowen JA: Effects of acute changes in neonatal leptin levels on food intake and long-term metabolic profiles in rats. Endocrinology 2011;152:4116-4126.

128 Attig L, Solomon G, Ferezou J, Abdennebi-Najar L, Taouis M, Gertler A, Djiane J: Early postnatal leptin blockage leads to a long-term leptin resistance and susceptibility to diet-induced obesity in rats. Int J Obes (Lond) 2008;32:1153-1160.

129 Viveros MP, Diaz F, Mateos B, Rodriguez N, Chowen JA: Maternal deprivation induces a rapid decline in circulating leptin levels and sexually dimorphic modifications in hypothalamic trophic factors and cell turnover. Horm Behav 2010;57:405-414.

130 Viveros MP, Llorente R, Diaz F, Romero-Zerbo SY, Bermudez-Silva FJ, Rodriguez de Fonseca F, Argente J, Chowen JA: Maternal deprivation has sexually dimorphic long-term effects on hypothalamic cell-turnover, body weight and circulating hormone levels. Horm Behav 2010;58:808-819. 